\title{
IMPROVING STUDENTS LEARNING MOTIVATION THROUGH MOBILE LEARNING
}

\author{
Alfiana Monika Sari ${ }^{1 *}$ and Heru Nurcahyo ${ }^{2}$ \\ ${ }^{1}$ Biology Education Department, Postgraduate, Universitas Negeri Yogyakarta, Special Region \\ of Yogyakarta, Indonesia \\ ${ }^{2}$ Biology Department, Faculty of Mathematics and Science, Universitas Negeri Yogyakarta, Special \\ Region of Yogyakarta, Indonesia \\ *Corresponding e-mail: alfimoonic@gmail.com
}

\begin{abstract}
One of the obstacles to achieving learning objectives is the low motivation of student learning. This study aimed to determine the improvement of students learning motivation through mobile learning. This preexperimental study consisted of 35 students of X IPA 1 as a subject while the population is all the students of State Senior High School 1 of Banguntapan - Yogyakarta. The sampling technique used purposive sampling. Data collection used questionnaires were given before and after learning. Data analysis used paired t-test and $\mathrm{N}$-gain score to see the effectiveness of mobile learning in increasing students learning motivation. The results showed that by using the mobile learning had a significant effect on students' learning motivation with a significance value $(\alpha)$ of $0.00<0.05$ while the $N$-gain score was included in the medium category, which was 0.64. The conclusions from this study indicate that mobile learning can increase learning motivation.
\end{abstract}

Keywords: Mobile learning, motivation, students, learning process.

(C) 2018 Department of Biology Education, FTTE, University of Muhammadiyah Malang, Indonesia

\section{INTRODUCTION}

Learning is an intellectual process that tries to direct students to achieve specified learning goals. The process occurs in a reciprocal relationship between teacher and student. Interactions that arise from both aim to obtain better indicators of student competency achievement. These competencies include cognitive, affective and psychomotor skills. In other words, the delivery of material in learning must be adapted to students' abilities and what competencies will be achieved after the learning (Berkowitz \& Hoppe, 2009; Gay, Mills, \& Airasian, 2012; Osuafor \& Amaefuna, 2016). On the other hand, the achievement of learning objectives cannot be separated from supporting components such as models, methods, and media. These components have a very significant effect in achieving learning success (Sanjaya, 2006). In the latest developments, all the components are integrated with technological developments.

The development of educational technology has developed rapidly in recent years (Capece \&
Campisi, 2013; Reiser, 2001; West, 2015). The existence of these technological developments encourages the emergence of other innovations that are diverse such as interactive learning media technology. The variations in learning media could be used to improve student learning experiences better. Through the use of media in determining it is expected to provide a more meaningful learning experience for students (Anjarwati, Winarno, \& Churiyah, 2016; Azhari, 2015; Loprinzi, Davis, \& Fu, 2015).

The next important thing in the learning process is motivation. As one of the important factors in the learning process, motivation can be used to predict the level of proficiency achieved by students in a given period (Filak \& Sheldon, 2008; Kusurkar, Ten Cate, Vos, Westers, \& Croiset, 2013; Zhu \& Zhou, 2012). Motivation describes processes that can energize human behavior and provide direction or purpose for certain behaviors (Sogunro, 2015). The behavior and attitudes of students in learning stems from learning motivation which in turn will affect the quality of learning outcomes (Kontaş, 2016; Saeed \& Zyngier, 2012; Schunk \& Zimmerman, 
2008). Well-developed motivation can promote long-term learning outcomes (Shin, Lee, \& Ha, 2017).

Achievement of biology learning is also inseparable from student learning motivation. Learning motivation is able to direct students in looking at learning objects and activating thinking skills that have an impact on learning outcomes. This is in accordance with Wicaksono, Minarti, and Roshayanti (2018) which says that motivation affects students' behavior in achieving their learning goals. Students who are intrinsically motivated will work hard and learn more because there is an inner urge to achieve their goals. Thus, a high level of students' motivation indirectly affect their achievement in science.

Increased learning motivation is also inseparable from the availability of learning devices (Harandi, 2015; Puspitorini, Prodjosantoso, Subali, \& Jumadi, 2014). Many studies have examined the development of biology learning media (Ajizatunnisa, Wahyuni, Waluyo, \& Miharja, 2018; Hidayah, Lumowa, \& Boleng, 2018; Ichsan, Rusdi, \& Sartono, 2017; Mitasari \& Gofur, 2017; Nur'aini, Chamisijatin, \& Nurwidodo, 2015; Widiansyah, Indriwati, Munzil, \& Fauzi, 2018). However, not many studies have examined the relationship between the uses of media to student learning motivation.

Based on the results of observations and interviews with biology teachers in Senior High School (SHS) 1 of Banguntapan, it was revealed that in the process of learning isolation and characterization of bacteria, teachers often encountered obstacles in preparing media such as how to present bacterial visualization in the learning process. This makes students less interested in learning about bacterial isolation and characterization. Students tend to be passive, such as waiting for instructions or waiting for the teacher to give assignments, some students do not pay attention, so they look sleepy $(17.14 \%)$; always speak out of context $(21.42 \%)$, and do other tasks (11.42\%). Besides, the schools do not have microbiology laboratories, so they often encounter limitations in the preparation of tools and materials in school laboratories to conduct isolation and characterization of bacteria.

One effort can be made to solve this problem by optimizing the use of innovative learning media. One of the media that can be used mobile learning (Mehdipour \& Zerehkafi, 2013). The use of mobile learning allows teachers and students to interact with learning resources.
These interactions stimulate an increase in student motivation and learning satisfaction (Harandi, 2015; Ljubojevic, Vaskovic, Stankovic, \& Vaskovic, 2014).

This study aims to determine the effect of mobile learning on student learning motivation. The results of this study are expected to contribute to mobile learning in the learning process that can increase student learning motivation.

\section{METHODS}

This study used pre-experiment with design one group pretest-posttest. The experimental group used Adobe Flash CS6 as a mobile learning about isolation and characterization of bacteria. The research design are presented in Table 1.

Table 1. One group pretest posttest design

\begin{tabular}{ccc}
\hline Before & Treatment & After \\
\hline $\mathrm{O}_{1}$ & $\mathrm{X}$ & $\mathrm{O}_{2}$ \\
\hline
\end{tabular}

Information:

$\mathrm{O}_{1}=$ motivation questionnaire before learning experiment group

$\mathrm{O}_{2}=$ motivation questionnaire after learning experiment group

$\mathrm{X}=$ learning using Adobe Flash CS6

This research was conducted at SHS 1 of Banguntapan, Bantul, Special Region of Yogyakarta Province. The population in this study were class X students as many as 192 students, while the research subjects were classes X.1 with 35 students indeed. The sampling technique uses purposive sampling. The instruments in this study consisted of 2013 curriculum syllabus, lesson plans, and motivation questionnaire sheets (Glynn, Brickman, Armstrong, \& Taasoobshirazi, 2011).

The data were analyzed using descriptive statistical analysis and inferential statistical analysis. Inferential statistical tests paired sample t-tests are used to test hypotheses (Hake, 1999). Then the data were analyzed using the SPSS 16.0 by paired sample t-test. If the criteria for $\mathrm{Ha}$ were accepted and $\mathrm{H}_{0}$ rejected was sig (2tailed) $<0.05$. Besides, the data were analyzed using the $\mathrm{N}$-gain score to determine the level of achievement of learning motivation isolation and characterization through mobile learning. Table of N-Gain category scores motivation can be seen in Table 2. 
Sari \& Nurcahyo / JPBI (Jurnal Pendidikan Biologi Indonesia) / 4 (3) (2018) pp. 271-276

Table 2. Conversion of N-Gain score to motivation

\begin{tabular}{cc}
\hline Normalized Gain Score & Level \\
\hline $\mathrm{g}>0.71$ & High \\
$0.31<\mathrm{g}<0.70$ & Medium \\
$\mathrm{g}<0.30$ & Low \\
\hline
\end{tabular}

\section{RESULT AND DISSCUSSION}

Based on the results, data are normally distributed with samples from the same variant population and the data variance is homogeneous. After that, the data were analyzed by paired sample t-test. The results of paired $t-$ test analysis can be seen in Table 3 .
The results showed that there are significant differences between the learning motivation of the students before and after learning with mobile learning $(0.00<0.05)$. Based on the range measurement of $\mathrm{N}$-Gain results, it is known that the students' motivation experimental is a medium category $(0.70>0.64$ $>0.30$ ). The results measurement of the $\mathrm{N}$-gain score learning motivation data in the experiment group can be seen in Table 4. Based on the calculation of the N-gain, it can be seen that the motivation for learning increases by using mobile learning (0.64) and was included in the medium category.

Table 3. The result of paired t-test learning motivation data in the experiment group

\begin{tabular}{cccccc}
\hline & t & df & Sig. (2-tailed) & Information \\
\hline Pair 1 & Pretest - Posttest & -31.343 & 34 & .000 & $\mathrm{H}_{0}$ rejected \\
\hline
\end{tabular}

Table 4. The results measurement of the $\mathrm{N}$-gain score learning motivation data in the experiment group

\begin{tabular}{|c|c|c|}
\hline Value & Pretest & Posttest \\
\hline Minimum value & 50 & 67 \\
\hline Maximum value & 78.33 & 93.33 \\
\hline Average & 59.14 & 85.36 \\
\hline $\begin{array}{l}\text { Average Gain Score } \\
\text { Category Gain Score }\end{array}$ & & \\
\hline
\end{tabular}

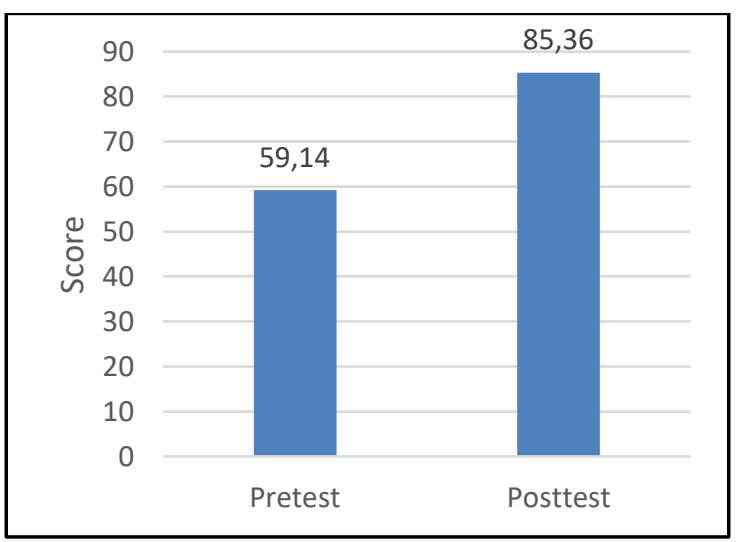

Figure 1. Increasing of students learning motivation

Based on Figure 1, it can be seen that the learning motivation score at pretest was 59.14, lower than the score obtained after learning using mobile learning at the posttest (85.36). Based on the calculation of the $\mathrm{N}$-gain, it can be seen that the motivation for learning increases by using mobile learning (0.64). This situation is under predictions because in mobile learning there are videos and pictures about the characteristics and results of bacterial isolation. Learning media containing videos can increase the motivation of students (Ebrahimzadeh \& Alavi, 2017). This material includes abstracts so that it is difficult if delivered without using effective learning media. Mobile media serves to present a visualization of learning objects that are very necessary to increase student motivation. Students' high learning motivation reflects thoughts, impulses, emotions, or desires to take specific actions that are meaningful in learning (Zhu \& Zhou, 2012).

Learning will be more comfortable and faster if you use mobile audio-visual learning compared to direct explanation. Learning to use mobile learning can explain abstract concepts more accessible to learn, besides that it can provide significant satisfaction and learning experience to students (Ashaver \& Igyuve, 2013; Rosli et al., 2015). Mobile learning is a crucial device that teachers can use to increasing students' motivation and education (Harandi, 2015). This is evidenced by the increasing learning motivation of students in this study when studying material isolation and bacterial characterization using adobe mobile learning.

The use of technology-based media is one of the practical approaches to be used in learning. When viewed from the side of media users, students who currently live in a period of digital technology are the right combination. So psychologically, the use of technology-based media can present good learning motivation 
because students can engage more deeply in the learning process (Alhassan, 2016; Capece \& Campisi, 2013). Wegner, Homann, and Strehlke (2014) also report that learning using electronicbased media can increase student motivation, while also enhancing better life skills in the future.

This is in line with the statement of Reiser (2001) which states that the use of appropriate learning media can convey information about objectives and learning the material to students, helps to remember the ability of prerequisites and motivates students to be happier and enthusiastic in the learning process. Learning media determine the effectiveness and efficiency of achieving learning goals, one of which is to increase learning motivation and make the learning atmosphere more interesting, so as to foster student learning motivation. (Azmi, 2015). Learning using computer-based learning can eliminate boredom and be able to respond to students to be active in the learning process so that it will produce good learning motivation and better cognitive learning outcomes (Andarini, Masykuri, \& Sudarisman, 2012). The use of computer-based learning media like video is also able to increase motivation, satisfaction, and success of learning (Ljubojevic et al., 2014). The use of computer-based learning media is also able to increase motivation, satisfaction, and success of learning (Aji, Hudha, Huda, \& Gufran, 2018). Increasing learning motivation in students is a good indicator to improve the learning process and learning outcomes (Leow \& Neo, 2014).

Based on the discussion and explanation from several sources above, it can be concluded that using mobile learning to improve learning motivation is felt to be appropriate and able to increase the learning motivation of students.

\section{CONCLUSION}

Based on the results of the analysis and discussion above, it can be concluded that the use of mobile learning can be improve learning motivation isolation and characterization of bacteria appropriately and effectively.

\section{REFERENCES}

Aji, S. D., Hudha, M. N., Huda, C., \& Gufran, G. (2018). Computer animation with adobe flash professional CS6 in Newton's Law.
IOP Conference Series: Materials Science and Engineering, 288(1). https://doi.org/ 10.1088/1757-899X/288/1/012131

Ajizatunnisa, A., Wahyuni, S., Waluyo, L., \& Miharja, F. J. (2018). Booklet development based on research identification of fiddler crab (Uca spp) diversity in mangrove ecosystem. JPBI (Jurnal Pendidikan Biologi Indonesia), 4(1), 61-66. https:// doi.org/10.22219/jpbi.v4i1.5337

Alhassan, R. (2016). Mobile learning as a method of ubiquitous learning: students' attitudes, readiness, and possible barriers to implementation in higher education. Journal of Education and Learning, 5(1), 176. https://doi.org/10.5539/jel.v5n1p176

Andarini, T., Masykuri, M., \& Sudarisman, S. (2012). Pembelajaran biologi menggunakan pendekatan CTL (contextual teaching and learning) melalui media flipchart dan video ditinjau dari kemampuan verbal dan gaya belajar. Jurnal Inkuiri, 1(2), 93-104.

Anjarwati, D., Winarno, A., \& Churiyah, M. (2016). Improving learning outcomes by developing instructional media-based Adobe Flash Professional CS 5.5 on principles of business subject. IOSR Journal of Research \& Method in Education, 6(5), 1-6. https://doi.org/10. 9790/7388-0605010106

Ashaver, D., \& Igyuve, S. M. (2013). The use of audio-visual materials in the teaching and learning processes in colleges of education in Benue State-Nigeria. IOSR Journal of Research \& Method in Education (IOSRJRME), 1(6), 44-55. https://doi.org/ 10.9790/7388-0164455

Azhari, A. (2015). Peran media pendidikan dalam meningkatkan kemampuan bahasa arab siswa madrasah. Jurnal Ilmiah Didaktika, 16(1), 43. https://doi.org/10.22 373/jid.v16i1.586

Azmi, M. (2015). Pengembangan ICT dalam pembelajaran. In Prosiding Workshop Nasional Pascasarjana Program Studi Teknologi Pendidikan Universitas Sebelas Maret (pp. 175-187). Surakarta: Universitas Sebelas Maret.

Berkowitz, M. W., \& Hoppe, M. A. (2009). Character education and gifted children. High Ability Studies, 20(2), 131-142. https://doi.org/10.1080/135981309033584 93

Capece, G., \& Campisi, D. (2013). User 
satisfaction affecting the acceptance of an e-learning platform as a mean for the development of the human capital. Behaviour and Information Technology, 32(4), 335-343. https://doi.org/10.1080/ 0144929X.2011.630417

Ebrahimzadeh, M., \& Alavi, S. (2017). The effect of digital video games on EFL students' language learning motivation. Teaching English with Technology, 17(2), 87-112.

Filak, V. F., \& Sheldon, K. M. (2008). Teacher support, student motivation, student need satisfaction, and college teacher course evaluations: Testing a sequential path model. Educational Psychology, 28(6), 711-724. https://doi.org/10.1080/0144341 0802337794

Gay, L. R., Mills, G. L., \& Airasian, P. (2012). Educational research: competencies for analysis and application. Boston: Pearson. Retrieved from http://englishlangkan.com/ produk/E Book Educational Research L R Gay Pearson 2012.pdf

Glynn, S. M., Brickman, P., Armstrong, N., \& Taasoobshirazi, G. (2011). Science motivation questionnaire II: Validation with science majors and nonscience majors. Journal of Research in Science Teaching, 48(10), 1159-1176. https://doi. org/10.1002/tea.20442

Hake, R. R. (1999). Analyzing change/gain scores. California.

Harandi, S. R. (2015). Effects of e-learning on students' motivation. Procedia - Social and Behavioral Sciences, 181, 423-430. https: //doi.org/10.1016/j.sbspro.2015.04.905

Hidayah, M. U., Lumowa, S. V. T., \& Boleng, D. T. (2018). Developing the archaebacteria and eubacteria web-based learning media for high school students. JPBI (Jurnal Pendidikan Biologi Indonesia), 4(2), 179-188. https://doi.org/10.22219/ jpbi.v4i2.5750

Ichsan, I. Z., Rusdi, R., \& Sartono, N. (2017). Hasil belajar sistem saraf menggunakan film pendek. Biosfer: Jurnal Pendidikan Biologi, 10(2), 49-59. https://doi.org/10. 21009/biosferjpb.10-2.7

Kontaş, H. (2016). The effect of an educationthemed movie on the academic motivation of teacher candidates and their attitude towards teaching profession. Journal of Education and Training Studies, 4(6), 93-
103. https://doi.org/10.11114/jets.v4i6.14 83

Kusurkar, R. A., Ten Cate, T. J., Vos, C. M. P., Westers, P., \& Croiset, G. (2013). How motivation affects academic performance: A structural equation modelling analysis. Advances in Health Sciences Education, 18(1), 57-69. https://doi.org/10.1007/s10 459-012-9354-3

Leow, F.-T., \& Neo, M. (2014). Interactive multimedia learning: innovating classroom education in a Malaysian University. TOJET: The Turkish Online Journal of Educational Technology, 13(2), 99-110.

Ljubojevic, M., Vaskovic, V., Stankovic, S., \& Vaskovic, J. (2014). Using supplementary video in multimedia instruction as a teaching tool to increase efficiency of learning and quality of experience. International Review of Research in Open and Distance Learning, 15(3), 275-291.

Loprinzi, P. D., Davis, R. E., \& Fu, Y.-C. (2015). Early motor skill competence as a mediator of child and adult physical activity. Preventive Medicine Reports, 2, 833-838. https://doi.org/10.1016/j.pmedr.2015.09.0 15

Mehdipour, Y., \& Zerehkafi, H. (2013). Mobile learning for education: benefits and challenges. In International Journal of Computational Engineering Research (Vol. 3, pp. 93-100). New Delhi.

Mitasari, Z., \& Gofur, A. (2017). Developing the Immunology Book for Animal and Human Physiology Subject. Jurnal Pendidikan Biologi Indonesia, 3(2), 141. https:// doi.org/10.22219/jpbi.v3i2.4325

Nur'aini, F., Chamisijatin, L., \& Nurwidodo, N. (2015). Pengembangan media berbasis multimedia interaktif untuk meningkatkan pemahaman siswa MAN 2 Batu materi kingdom animalia. JPBI (Jurnal Pendidikan Biologi Indonesia), 1(1), 3546.https://doi.org/10.22219/jpbi.v1i1.2301

Osuafor, A. M., \& Amaefuna, I. A. (2016). A survey of biology teachers use of activityoriented, laboratory practical exercises to promote functional biology education. Education and Learning (EduLearn), 10(3), 281-290. Retrieved from http:// journal.uad.ac.id/index.php/EduLearn/arti cle/view/3952/2556

Puspitorini, R., Prodjosantoso, A. K., Subali, B., \& Jumadi, J. (2014). Penggunaan media 
komik dalam pembelajaran ipa untuk meningkatkan motivasi dan hasil belajar kognitif dan afektif. Jurnal Cakrawala Pendidikan, 3(3), 413-420. https://doi.org/ 10.21831/cp.v3i3.2385

Reiser, R. A. (2001). A history of instructional design and technology: Part 1: A history of instructional media. Educational Technology Research and Development, 49(1), 53-64. Retrieved from http://www. jstor.org/stable/30220299

Rosli, M. S., Saleh, N. S., Aris, B., Ahmad, M. H., Sejzi, A. A., \& Shamsudin, N. A. (2015). E-learning and social media motivation factor model. International Education Studies, 9(1), 20. https://doi.org /10.5539/ies.v9n1p20

Saeed, S., \& Zyngier, D. (2012). How motivation influences student engagement: A qualitative case study. Journal of Education and Learning, 1(2), 252-267. https://doi.org/10.5539/jel.v1n2p252

Sanjaya, W. (2006). Strategi pembelajaran (berorientasi standar proses pendidikan) (Vol. 1). Jakarta: Prenadamedia Group.

Schunk, D. H., \& Zimmerman, B. J. (2008). Motivation and self-regulated learning: theory, research, and applications. New York: Lawrence Erlbaum Associate.

Shin, S., Lee, J.-K., \& Ha, M. (2017). Influence of career motivation on science learning in Korean high-school students. Eurasia Journal of Mathematics, Science and Technology Education, 13(5), 1517-1538. https://doi.org/10.12973/eurasia.2017.006
$83 \mathrm{a}$

Sogunro, O. A. (2015). Motivating factors for adult learners in higher education. International Journal of Higher Education, 4(1), 22-37. https://doi.org/10.5430/ijhe. $\mathrm{v} 4 \mathrm{n} 1 \mathrm{p} 22$

Wegner, C., Homann, W., \& Strehlke, F. (2014). Electronic learning in the German science project "Nawi-Interaktiv." European Journal of Science and Mathematics Education, 2(4), 220-222.

West, D. M. (2015). Connected learning: How mobile technology can imporve education. Center for Technology Innovation at Brookings, (December), 1-8.

Wicaksono, A. G. C., Minarti, I. B., \& Roshayanti, F. (2018). Analysis of students' science motivation and nature of science comprehension in middle school. Jurnal Pendidikan Biologi Indonesia, 4(1), 35-42. https://doi.org/10.22219/jpbi.v4i1. 5354

Widiansyah, A. T., Indriwati, S. E., Munzil, \& Fauzi, A. (2018). I-invertebrata as an android-based learning media for molluscs, arthropods, and echinoderms identification and its influence on students' motivation.

JPBI (Jurnal Pendidikan Biologi Indonesia), 4(1), 43-52. https://doi.org/10. 22219/jpbi.v4i1.5476

Zhu, B., \& Zhou, Y. (2012). A study on students' affective factors in Junior high school English teaching. English Language Teaching, 5(7), 33-41. https://doi.org/10. 5539/elt.v5n7p33 